\title{
LAICISMO, LIBERDADE RELIGIOSA E EDUCAÇÃO NO BRASIL NA PERSPECTIVA DO APOSTOLADO POSITIVISTA (1880-1930)
}

\author{
João Carlos da Silva ${ }^{1}$
}

\section{Resumo}

Neste artigo, discutimos sobre o papel do Apostolado Positivista do Brasil nos encaminhamentos acerca do laicismo na Primeira República. A questão religiosa ocupou parte dos debates desde o Império, mobilizando políticos, intelectuais e homens de negócios. Esse tema tem sido objeto de muitos autores, entre eles Cunha (2013, 2017), Saviani (2007) e Junqueira (2002). A tentativa de tornar o Ensino Religioso facultativo nas escolas foi uma longa trajetória marcada por contradição, avanços, recuos, conflitos e conciliações. Nesse cenário, é importante compreender as formas assumidas pelo religioso no Brasil, merecendo ser revisitado e analisado dentro da peculiaridade brasileira. No começo da República, o campo religioso ficava cada vez mais complexo. Os positivistas reconheciam a Igreja Católica, porém, não desejavam submeter-se aos seus representantes.

Palavras-chave: Laicidade. Educação. Positivismo. Liberdade religiosa.

\section{RELIGIOUS LIBERTY AND EDUCATION IN BRAZIL IN THE PERSPECTIVE OF THE POSITIVIST APOSTOLATE (1880-1930)}

\begin{abstract}
In this article we discuss the role of the Positivist Apostolate of Brazil in the referrals about secularism in the face of the hegemony of Catholicism in the First Republic. The religious question has occupied much of the debates since the Empire, mobilizing politicians, intellectuals and businessmen. This topic has been the subject of many authors, among them Cunha (2013, 2017), Saviani (2007) and Junqueira (2002). The attempt to make Religious Education facultative in schools was a long trajectory marked by contradiction, advances, retreats, conflicts and conciliations. In this scenario it is important to understand the forms assumed by the religious in Brazil, deserving to be revisited and analyzed, within the Brazilian peculiarity. At the beginning of the Republic the religious field became increasingly complex. The positivists recognized the Catholic Church, but they did not wish to submit to it, nor to their representatives.
\end{abstract}

Keywords: Laicity. Education. Positivism. Religious freedom.

\section{LAICISMO, LIBERTAD RELIGIOSA Y EDUCACIÓN EN BRASIL EN LA PERSPECTIVA DEL APOSTOLADO POSITIVISTA (1880-1930)}




\section{Resumen}

En este artículo discutimos el papel del Apostolado Positivista de Brasil en los encaminamientos acerca del laicismo frente a la hegemonía del catolicismo en la Primera República. La cuestión religiosa ocupó gran parte de los debates desde el Imperio, movilizando políticos, intelectuales y hombres de negocios. Este tema ha sido objeto de muchos autores, entre ellos Cunha (2013, 2017), Saviani (2007) y Junqueira (2002). El intento de hacer la Enseñanza Religiosa facultativa en las escuelas fue una larga trayectoria marcada por contradicción, avances, retrocesos, conflictos y conciliaciones. En este escenario es importante comprender las formas asumidas por el religioso en Brasil, mereciendo ser revisitado y analizado, dentro de la peculiaridad brasileña. En el comienzo de la República el campo religioso quedaba cada vez más complejo. Los positivistas reconocían a la Iglesia Católica, pero no deseaban someterse ni a ella, ni a sus representantes.

Palabras clave: Laicidad. Educación. Positivismo. Libertad religiosa.

\section{INTRODUÇÃO}

Passados mais de cem anos, assistimos à retomada do debate acerca da oferta do ensino religioso nas escolas, ganhando contornos de judicialização, mediante ação apresentada pela Procuradoria Geral da República (PGR) ao Supremo Tribunal Federal (STF) propondo que as aulas se limitassem à exposição das doutrinas, história, práticas e dimensões sociais das diferentes crenças. A luta pela laicidade foi travada no campo da educação pública com algumas conquistas e retrocessos que merecem ser observadas. A laicidade, em face do seu caráter polissêmico, é um termo que designa diferentes campos do saber, como o filosófico, jurídico e histórico ${ }^{2}$. Esse tema tem sido objeto de muitos autores, entre eles Cunha (2013, 2017), Saviani (2007) e Junqueira (2002).

Devemos reconhecer que a laicidade desempenhou um papel importante na história educacional do Brasil que merece ser revisitado e analisado, mas dentro da peculiaridade brasileira, ainda que modelos de laicidade fossem buscados na Europa, notadamente na França, para encaminhar por aqui a questão da liberdade religiosa.

A questão religiosa ocupou grande parte dos debates desde o Império, mobilizando políticos, intelectuais e homens de negócios. A tentativa de tornar o Ensino Religioso facultativo nas escolas foi uma longa trajetória marcada por muita contradição, avanços, recuos, conflitos, negociação e conciliação. Grosso modo, o Catolicismo tinha aversão à separação entre a Igreja e o Estado, igualmente rejeitava a liberdade para todos os cultos, por razões óbvias, afinal, a maioria da população brasileira era constituída por católicos. Nesse cenário, é importante compreender as formas assumidas pelo religioso na história do Brasil em relação a outros países. 
Desde as Constituições de 1824 e1891, a secularização do ensino foi tema de muita discussão, apesar das propostas dos positivistas ortodoxos de romperem com os privilégios do catolicismo. Esses exerciam forte oposição ao clericalismo, cujo contexto foi denominado por Cunha (2017) como primeira onda laica no campo educacional. A constituinte de 1987 foi cenário de acirradas disputas entre católicos, laicos, liberais e outros agrupamentos religiosos que já disputavam hegemonia em torno do ensino religioso nas escolas ${ }^{3}$.

Os positivistas, na passagem do século XIX para o século XX, foram protagonistas da laicidade do Estado ao defenderem uma escola laica, por meio da substituição do currículo com marcas de religiosidade por um currículo enciclopédico, com a inclusão das disciplinas. Foi um período de radicalização entre positivistas e católicos, havendo registros de atentado, acusações e agressões de ambos os lados $^{4}$, considerados inimigos da Igreja e de todo seu sacerdócio na medida em que se achavam herdeiros do catolicismo.

Tal posição tinha a finalidade de romper com a tradição pedagógica católicohumanista. Por outro lado, os avanços jurídicos e filosóficos não foram suficientes para conter o ímpeto religioso que estava impregnado na sociedade brasileira depois de mais de 200 anos de domínio da pedagogia jesuítica. Os positivistas eram uma ameaça aos interesses da Igreja Romana, sobretudo daqueles setores mais conservadores 5 .

A rigor, o processo de laicidade no Brasil é, no mínimo, controverso. A Proclamação da República, ao declarar a separação Estado-Igreja, suprimiu os subsídios financeiros ao clero, garantiu liberdade de culto, secularizou os cemitérios públicos e determinou que as escolas públicas fossem laicas, isto é, livres do Ensino Religioso. Todavia, isentou as instituições religiosas de pagarem impostos e de outros encargos obrigatórios, consideradas pelos seus opositores como regalias.

É viável pensar em um ensino laico na medida em que a Igreja ou as Igrejas estiveram sempre imbricadas ao poder estabelecido? É possível um ensino laico em um país com alto grau de religiosidade como o Brasil? Estaria a laicidade ameaçada diante do avanço da religiosidade e da diversidade de credos? Neste artigo, temos como objetivo discutir a questão do laicismo e da religião a partir das ações empreendidas pelos positivistas nos encaminhamentos educacionais no final do século XIX.

\section{POSITIVISMO E LAICISMO}

A República, no Brasil, fundada sobre os alicerces do progresso, da democracia e do pensamento liberal, marcou o desenvolvimento e a disseminação do positivismo como doutrina de grande influência nos debates acerca da reorganização do ensino e de sua função na sociedade. Nesse cenário, caberia à educação auxiliar na formação de novos hábitos, da mente, do caráter e de padrões morais. 
Aos olhares dos positivistas, estava em jogo substituir a antiga civilização teológicomilitar, em seu último estágio católico-feudal, pelo moderno regime pacífico-industrialpositivista, no sentido de estimular e orientar a transição que era uma meta natural da evolução humana.

Escritores de renome também se insurgiam contra os privilégios da Igreja, entre eles Manoel Antônio de Almeida, Aluísio de Azevedo e Raul Pompéia, no sentido do seu afastamento em relação ao Estado. As escolas oficiais tinham o catolicismo como conteúdo obrigatório para todos os alunos, motivo de constrangimento aos adeptos de outra religião. A década de 1870 trouxe novos elementos a esse tensionamento. A relação Estado-Igreja precisava ser enfrentada e encaminhada, pois dela dependiam outras tomadas de decisões, como o incentivo à vinda dos imigrantes que, em sua maioria, eram protestantes. Saindo dos conflitos religiosos na Europa, esses não queriam ter aqui problemas semelhantes, ao contrário, desejavam uma condição de vida livre das perseguições religiosas. Assim, superar a questão religiosa era urgentemente dar vazão a muitos outros desafios.

Ainda que sob pressões, o silêncio da Igreja Católica em relação à escravidão tornouse um motivo importante para que a questão da liberdade religiosa fosse resolvida, conforme o que havia se encaminhado em grande medida na Europa. O laicismo se tornou palavrachave nesse período, conforme já se observa na Constituição de 1824, no Art. 72, sobre a declaração de direitos: "Todos são iguais perante a lei [...] Todos os indivíduos e confissões religiosas podem exercer pública e livremente o seu culto [...] Será leigo o ensino ministrado nos estabelecimentos públicos." (BRASIL, 1986).

A primeira Carta republicana, de 1891, também expressou esse ideário. Grosso modo, no Império, Cidadão era aquele que professava o Catolicismo. A partir desse pressuposto, os negros e os índios, com suas manifestações politeístas, não entravam para esse rol. Em outros termos, os escravos negros e índios necessitavam de educação, mas não de instrução, isto é, religião sim, escola não. Diante desse quadro, o movimento do laicismo ganhava cada vez mais força com contornos de confronto, ora camuflado, ora a céu aberto, sobretudo daqueles líderes religiosos alinhados com Roma.

As posições contrárias no parlamento bem como nos debates públicos, contrários à hegemonia católica, custavam caro àqueles que assim se colocassem, fato que muitas vezes comprometia uma eleição no futuro pleito ${ }^{6}$. A Constituição de 1891 procurou conciliar projetos liberais de secularização e descentralização do ensino com as propostas positivistas de romper com os privilégios do catolicismo. O Art.72, por exemplo, determina ser leigo o ensino ministrado nas escolas estatais. O Art. 34 estabelece competência exclusiva ao Congresso Nacional em legislar sobre o ensino superior na capital federal. O Congresso Nacional poderia criar, mas não privativamente, instituições de ensino superior nos estados. Assim, fora da capital do país, tanto o Congresso Nacional quanto as Assembleias Legislativas Estaduais poderiam criar escolas superiores. 
Presbiterianos, luteranos, maçons e positivistas engrossavam o movimento em favor da liberdade religiosa. O ímpeto da contrarreforma renascia no seio do Catolicismo como reação à perda da coesão e hegemonia, ameaçada, sobretudo no campo da educação escolar, pelas chamadas "seitas clandestinas". Aos olhares do Apostolado Positivista, o real cumprimento dos preceitos constitucionais era parte do processo de regeneração social mediante à intransigente defesa do regime pacífico-industrial, da preservação das liberdades civis e políticas e dos princípios de fraternidade universal. Para eles, a educação deveria assumira responsabilidade de disseminar e desenvolver o espírito cívico.

A educação aparecia na Constituição de 1824, em seu título VIII, como: "As garantias dos direitos civis e políticos dos cidadãos brasileiros.” (BRASIL, 1986, p. 89). Esse princípio é reafirmado na Carta de 1891, no capítulo sobre a "Declaração dos Direitos". Assim, a "[...] gratuidade do ensino primário a todos os cidadãos." (BRASIL, 1986, p. 89). Declarada na Constituição imperial, caracterizou-se mais como uma retórica do que propriamente resultado de uma exigência social, não fazendo parte, ainda, das políticas sociais regidas pelo Estado.

\section{O APOSTOLADO POSITIVISTA E A EDUCAÇÃO LAICA}

A laicidade do Estado, componente da plataforma positivista, reivindicava o fim do Catolicismo como religião oficial, indo ao encontro às bandeiras de liberais, protestantes e maçons. Os positivistas, ao atuarem com base em um conjunto de leis consideradas universais, entendiam que o mundo se achava em uma grande transição do catolicismo para o positivismo.

O Ensino Religioso nas escolas públicas logo entraria na pauta dos debates. Naquele momento de maioria católica, pensar em um país ausente de religião nas escolas seria, segundo os líderes do catolicismo, uma pátria sem futuro, uma tragédia moral. Uma questão intrigava a todos: se a Igreja Católica não desejava ministrar o Ensino Religioso, delegando tal função às escolas, o que ela fazia então neste mundo?

No discurso pronunciado na reunião entre os republicanos no dia 15 de agosto de 1881, Miguel Lemos tornava público a concepção de educação. Para ele, educação é uma doutrina que forneceria regras de conduta para todos os atos da vida, podendo realizar-se somente pelo regime da completa liberdade espiritual. (PAIM, 1981, p. 13). As garantias da liberdade do espírito consistiam nos principais valores de uma sociedade, condição necessária para a solução do grande problema do nosso tempo: reorganizar a sociedade sob a preponderância do positivismo.

A separação do poder espiritual e poder temporal, ainda no século XVIII, não foi suficiente para resolver a questão da liberdade religiosa. Os positivistas queriam suprimir a influência católica na vida brasileira ao considerar que a Igreja de Roma já havia prestado 
relevantes serviços ao Brasil e à América Latina, mas que a partir daquele momento deveria submeter-se às determinações do Estado.

Eles não se consideravam menor que o catolicismo; a única diferença é que os positivistas se referiam ao Ser Supremo como sendo a Humanidade, enquanto que a Igreja, a Deus. (MENDES, 1907). Era muito comum desavenças entre lideranças da Igreja Católica e do Apostolado Positivista em razão das tentativas dos primeiros em insistirem na manutenção de subsídios e de privilégios e outras regalias por parte do poder público. Eles exigiam os confiscos dos bens e imóveis pertencentes à Igreja, o que geravam muitos conflitos.

Era comum as lideranças do clero, entre eles bispos e padres, convocarem seus fiéis a defenderem a Igreja contra os ataques públicos proferidos pelos positivistas, considerados principais inimigos da Igreja, inclusive mobilizando a população a não votarem nos candidatos que assim se comportassem. A rigor, os representantes do Apostolado Positivista se consideram legítimos herdeiros do catolicismo, assim como o catolicismo fora o sucessor do Judaísmo, visto como uma tendência natural dos acontecimentos, o que causava fortes reações dos católicos.

A repulsa do catolicismo à República foi o fato de ela assumir um discurso anticatolicista. Algumas bandeiras foram colocadas pelos representantes do clero como condições sine qua non para manifestar apoio à República: que o Ensino Religioso voltasse para a escola pública; que houvesse registro civil dos casamentos, mas que não se declarasse como o único válido; que não se proibisse a criação de conventos e ordens religiosas; e que não se expulsassem padres educadores.

Outros pontos foram pacientemente acordados, a saber, secularização dos cemitérios públicos, casamento civil, Ensino Religioso facultativo nas escolas públicas, ensino laico nas escolas públicas e separação Igreja(s) e Estado. Ficaram de fora o Espiritismo kardecista, os cultos indígenas, afro-brasileiros e outros. A rigor, estava em curso uma "separação amigável" cuja ajuda mútua seria discretamente ofertada.

No começo da República, o campo religioso ficava cada vez mais complexo e inseguro. $\mathrm{O}$ que estava sendo colocado em causa, tanto na Europa quanto no Brasil, era a posição dominante da Igreja. Os positivistas reconheciam a Igreja Católica, porém, não desejavam se submeterem a ela e nem aos seus representantes. Nas palavras de Teixeira Mendes (1912), representando a posição do positivismo ortodoxo, a catolicismo havia atingido sua exaustão.

A máxima dos positivistas "O amor por princípio, a ordem por base, o progresso por fim" era princípio que inspirava suas lutas ao afirmarem com convicção o positivismo como a "nova Religião da Humanidade" a partir daquele momento, capaz de instaurar a fraternidade universal. Caberia a essa "Nova Igreja", considerada a síntese desse desfecho histórico, realizar a grande transição da antiga para a nova ordem, desarticulando os ímpetos de violência, da agressão e de conflitos entre ricos e pobres, sobretudo na Europa. 
A Religião da Humanidade, denominação dada pelos ortodoxos do positivismo, teria sido resultado da inevitável evolução da humanidade para estabelecer a harmonia completa e a fraternidade universal ${ }^{7}$.

A grande marcha na direção do entendimento humano, da plenitude religiosa e da solução definitiva da anarquia espiritual consistiria na subordinação do progresso à ordem, da análise à síntese e do egoísmo ao altruísmo, considerados inatos nos indivíduos e comprovados pela ciência da época calcada na máxima fundamental do Apostolado Positivista: O Amor por princípio, a Ordem por base, o Progresso por fim. A doutrina positivista, ao propor uma completa reforma social pela educação, partia de uma nova mentalidade de inspiração altruísta, para organizar uma sociedade industrial pacífica.

No Discurso preliminar sobre o conjunto do positivismo (1848), Comte (2000b) apresenta a doutrina como uma "nova religião" a ser seguida, anunciando a decadência de uma "velha religião" amparada em um "Deus" supremo. O culto à Humanidade se torna eixo central da religião positivista, amparado na trilogia: pensamentos, atos e sentimentos. (SILVA, 2016).

Consolidando uma "Nova Era", institui-se um novo calendário e sistema de feriados em homenagem aos grandes heróis da humanidade do Mundo Antigo. Carregado de simbologias, o positivismo religioso anunciava a chegada de um novo tempo, inaugurando a fase da grande conciliação universal. Observando os acontecimentos na França, no Brasil, os positivistas viam a necessidade de organizar um novo espaço público de liberdade religiosa. A religião positivista exigia reformar as antigas instituições do Império, visando implementar uma nova concepção de sociedade. Enquanto no país de Comte a laicidade dava ações religiosas, a separação Estado-Igreja era para "Inglês ver".

Alberto Salles (1857-1904), personalidade de destaque entre os denominados intelectuais ilustrados na propaganda positivista, em seu ensaio Observações preliminares à ciência política, sintetiza o entendimento sobre a ideia de organização do ensino necessário para o Brasil ao mesmo tempo em que estabelece a função do Estado nesse setor de acordo com as prescrições de Augusto Comte:

\footnotetext{
Para o ensino público tomar assim um caráter social é preciso, todavia, que ele seja livre ou descentralizado, gratuito ou generalizado, leigo ou absolutamente neutro e integral ou científico e profissional. [...] A função do Estado já não consiste, como observa Yves Guyzot, em governar, mas em administrar; governar quer dizer ir às pessoas; e administrar, imprimir ordem e direção às coisas. A centralização do ensino é um monopólio que o Estado constituiu com grande detrimento da consciência nacional; é urgente extirpá-lo de uma vez da nossa organização política. (SALLES, 1890 apud PAIM, 1981, p. 55).
}

A preocupação de Comte e de seus seguidores no Brasil era com a necessidade urgente do encerramento da Revolução Francesa e seus intermináveis desdobramentos, ciclo que ainda não se havia completado. 


\title{
Artigo
}

doi: $10.20396 /$ rho.v18i4.8653196

Os seguidores de Comte tinham como referência e modelo de laicização os acontecimentos da França, desde a Revolução Francesa, vendo similaridades no que poderia ocorrer no Brasil a partir da Lei de $1905^{8}$. Desejavam acelerar a laicização por aqui, não levando em conta as particularidades das lutas e embates que se deram e marcaram o movimento pela laicização em ambos os países. O estabelecimento radical da liberdade religiosa no Brasil deveria se similar ao ocorrido em terras francesas. Nessa jornada, exigia-se muita energia e coragem, para tanto, se aproxima aqueles que igualmente desejavam instaurar uma nova ordem religiosa:

\begin{abstract}
Maçonaria e o Positivismo eram concorrentes no plano filosófico, mas aliados na política prática brasileira, principalmente a partir da década de 1870, quando tinham importantes metas comuns, como a abolição da escravatura, a secularização da cultura e a laicidade do Estado, para o que a retirada do privilégio de religião oficial da Igreja Católica era condição necessária. A Maçonaria estava bem difundida no país, mas o Positivismo cresceu especialmente nas escolas de Engenharia e na Academia Militar. (CUNHA, 2017, p. 306).
\end{abstract}

A regeneração da humanidade era parte constitutiva da concepção educacional republicana, centrada na ideia da reforma mental. O estado mental do indivíduo era atribuído à precariedade das próprias instituições, entre elas as empresas, a Igreja, a família e as instituições educacionais. Preconizava-se a realização de uma ampla reforma, começando pelo regime político, passando por todas as instituições, especialmente a família, para atingir a mente dos indivíduos:

O estudo sientífico da sociedade e do hômen demonstra:

$1^{\circ}$ Que o ensino da primeira e da segunda infância, - essencialmente estético, compéte às Mãis ou a quem suas vezes fizér: $2^{\circ} \mathrm{O}$ ensino da adolecência, essencialmente filozófico, isto é, fornecendo o conhecimento sintético do mundo, da sociedade e do hômem, mediante o estudo sucessivo da matemática da astronomia, da fízica, da quimica, da biologià, da sociologia e da moral, - compéte ao Poder esperitual ou Sacerdócio; $3^{\circ} \mathrm{O}$ ensino profissional está ligado ao ezercício das divérsas funções, em virtude da preparação filozófica adquirida na adolecência. Assim, um agricultor, um engenheiro, um piloto, um banqueiro, um cirurgião, um médico, etc., da mesma sórte, que o mais modéstio operário, formão-se, - depois do ensino filozófico peculiar à adolecência, ou a par desse ensino, - ezercendo éssas funções, desde os graus inferiores até os superiores, sob a direção dos práticos agricultores, engenheiros, pilotos, banqueiros, médicos, etc., - na prática efetiva qüotidiana e não em escolas. (MENDES, 1936, p. 137-138).

Mendes (1936) fazia severas críticas à organização do ensino, sobretudo em relação ao ensino primário. A vida doméstica deveria assumir papel mais importante do que o ensino primário, especialmente em relação ao seu caráter obrigatório. $\mathrm{Na}$ visão do Apostolado Positivista, o ensino exigia, em primeiro lugar, a organização da vida doméstica, de maneira que a mulher pudesse exercer plenamente a sua insubstituível e incomparável função educadora. A escola primária, nesse sentido, era uma usurpação da função materna e, por conseguinte, a mais grave das usurpações, a mais nociva à sociedade. 


\section{Artigo}

doi: $10.20396 /$ rho.v18i4.8653196

Mendes (1936) aponta que o esvaziamento da ação política do seu conteúdo educacional tinha como causa o estado de apatia e de desânimo em que o país estava envolvido, decorrente de uma cultura educacional disseminada ao longo do Império. Nesse momento, o ensino voltado para a adolescência exigia uma doutrina e dignos organizadores dessa doutrina. Para tanto, o governo temporal deveria suprimir toda forma de intervenção. Com a chegada de Vargas ao poder, veremos um abrandamento das posições anticlericais inclusive no âmbito da laicidade. A rigor, logo se percebia que a luta pela laicidade se resumia a uma minoria. As práticas conciliatórias, características da nossa vida política, longe de qualquer radicalismo extremo e dos acordos por cima, foram o desenlace deste interminável dilema.

\section{O POSITIVISMO COMTIANO E A EDUCAÇÃO}

No Curso de Filosofia Positiva, publicado em 1832, Comte estabeleceu conceitos e princípios básicos acerca do entendimento sobre a inteligência humana, uma vez que no seu projeto de regeneração do ocidente o homem deveria ser aperfeiçoado mediante um novo plano educacional. A evolução da humanidade, para o filósofo, havia se dado de forma espontânea. Entretanto, a ciência possibilitou uma "sábia" intervenção em seu desenvolvimento, uma vez que pôde apreender as leis que regulavam a marcha do desenvolvimento humano, fundadas na entidade abstrata da humanidade.

É bom destacar que o ponto de partida, o teológico, é o mesmo caminho para o desenvolvimento da inteligência como para a educação do indivíduo. Do mesmo modo, Comte aponta que todos os indivíduos, durante o desenvolvimento, passam por esses três estágios: o estado teológico da infância; o estado metafísico da juventude; e o estado positivo na virilidade, ou a maturidade. Quanto à atividade humana, há uma correspondência aos estados supracitados, a saber, no princípio, conquistadora, depois, defensiva e, finalmente, industrial.

Segundo Comte, a evolução levou o homem a trabalhar primeiro para a família; depois para a pátria, por causa da família; e, finalmente, para a humanidade, por meio da família e da pátria. Tanto o ensino da criança quanto do adolescente deveria garantir um currículo mínimo, como ensinamentos sobre leitura, escrita, cálculo elementar aritmético, canto e desenho, utilizando, para isso, alguns estudos práticos vindos da França e da Itália. Mesmo assim, esse estudo respeitaria as indicações das mães, as quais escolheriam os assuntos a serem lidos, escritos, cantados e desenhados.

Garantindo esses conhecimentos mínimos, aqueles que tiverem capacidade teórica poderão ampliar ou seguir seus estudos frequentando bibliotecas, museus e laboratórios. A mãe deveria assumir, como função natural e sacerdotal, o ensino da primeira e da segunda infância, dever fundado na doutrina universalmente aceita, cujos princípios definiriam os deveres de todos para com todos. Tal doutrina deveria compreender: 
Philosophia Primeira ou apreciação das quinze leis universaes da Suprema Ordem abastracta; A Philosophia Segunda ou apreciação da gerarquia constituída pela mathematica ou lógica, astronomia, physica, chimica, biologia e moral, tanto theorica como pratica; Philosophia Terceira ou apreciação do conjunto da acção real e útil da Humanidade sobre a Terra, organizando a Industria para completar a Ordem natural. (MENDES, 1913, p. 8).

Os positivistas defendiam uma escola livre, laica, por meio da substituição do currículo acadêmico por um currículo enciclopédico, com a inclusão das disciplinas científicas, como Matemática, Astronomia, Física, Química, Biologia, Sociologia e Moral, com forte inspiração positivista, com a finalidade de romper com a tradição pedagógica católico-humanista.

Tratava-se, então, de suprimir dos currículos aqueles elementos que ensejavam a formação cristã, incorporando uma doutrina que difundisse os valores do nacionalismo e da cidadania, dentro de um clima de entusiasmo patriótico. Mendes (1936), ao indicar o ideário educacional republicano, define a concepção de educação tão cara aos positivistas da seguinte maneira:

\footnotetext{
O bem público ezige simplesmente saber ler e escrever e ser letrado; o bem público ezige que se possúão conhecimentos reais e úteis sobre o mundo, a sociedade e o hômem. Mas, acima disso, e como condição impescindível para isso, tórna-se necessário que os que ensínão os que aprêndem estejão animados realmente pelos sentimentos altruístas. (MENDES, 1936, p. 132).
}

O ensinamento positivista indicava em relação ao ensino em geral que o homem deveria ser educado para adquirir uma personalidade moral. O programa escolar estava organizado dos 7 aos 14 anos, por meio do "Canto, escultura e desenho, antecedendo a leitura e a escrita." A primeira fase consistia dos 7 aos 8 anos. Os conteúdos estavam centrados em grandes temas geradores como: "O espaço, o Céu, o Ar e a Água, a Terra, as Plantas, Os animais e a Humanidade.” (MENDES, 1936, p. 132).

Comte julgava o mundo moderno como uma época de desordem econômica, política, moral e intelectual, apontando, como solução, a necessidade de uma nova filosofia "[...] só a filosofia positiva pode ser considerada a única base sólida da reorganização social, que deve terminar o estado de crise no qual se encontram, há tanto tempo, as nações mais civilizadas." (COMTE, 2000b, p. 39). Suas obras não trataram exclusivamente sobre a questão educacional. Seus conteúdos expressavam uma profunda crença no processo educativo, ancorado numa ciência emergente, como instrumento de salvação da sociedade, ideal característico da concepção moderna de educação. Ciência, daí previdência; previdência, daí ação.

A filosofia comtiana idealizava um homem prático, empírico e empreendedor mediante à valorização de uma educação utilitarista. Convictos desses princípios, Teixeira Mendes e Miguel Lemos, dirigentes da IP, elaboram um conjunto de propostas educacionais, apontando a filosofia positivista como solução dos problemas enfrentados pela sociedade 
brasileira, sobretudo no campo educacional, reafirmando a superação da pedagogia católica considerada obsoleta e incapaz de responder às novas demandas colocadas pela sociedade brasileira:

\begin{abstract}
[...] éssa educação é um amontoado híbrido das vélhas doutrina teológicas e metafízicas e dos fragmentos incomplétos e amiúdo falsos da siência, e que éla não se dirige como devia ser, à grande massa social, ao proletariado. Mentira tanto mais perigóza e retrógrada quanto se trata justamente hoje de fazer surgir e predominar a fé demonstrável sobre a qual déve fundar-se a verdadeira educação nacional, isto é, um ensino que, compreendendo todas as siências, desde a matemática até a moral, terminará assinalando a todos os cidadãos os seus deveres respetivos, de acordo com as divérsas funções que eles são chamados a preencher na sociedade. (MENDES, 1936, p. 57).
\end{abstract}

A educação escolar, que deveria atender a todos (pobres, ricos, crianças e adultos), tornou-se sinônimo de disciplina do hábito, cujo objetivo estava em implementar uma pedagogia higiênica voltada à formação do futuro operário. Mendes (1936) assevera a necessidade de uma reforma geral do ensino nos seus mais diferentes níveis, devendo eliminar, especialmente, seu componente católico. Os ensinamentos positivistas, ao serem apresentados como a única filosofia capaz de ocupar o vazio deixado, exigiam a depuração do ensino quanto a todo o seu conteúdo religioso, notadamente de base católica, pela supressão de todo o ensino pedantocrático mantido pelo Estado, e que mantinha a nação inteira sob seu jugo. Era preciso oferecer um ensino prático da sociologia e da moral científicas, colocando suas principais leis ao alcance do conhecimento universal. (MENDES, 1908).

O espírito intelectual positivista apresentava uma perspectiva otimista em relação ao futuro, cultivando uma esperança de edificar uma nova realidade, por conta do desenvolvimento da indústria na Europa. $\mathrm{O}$ apostolado se achava envolvido na luta teórica e prática pela instauração de uma nova proposta pedagógica, ou seja, de um novo conteúdo nas escolas, para formar um novo homem. O surto da industrialização, do nacionalismo e do patriotismo conquistavam cada vez mais uma importante parcela dos intelectuais. As elites, incomodadas com a situação do analfabetismo, entendiam ser esse um dos entraves ao desenvolvimento e a modernização do país.

A ideia de educação estava relacionada à questão de capacitação e da formação de novas gerações no sentido de mudança de determinados valores, crenças, tradições e práticas sociais e exigiam a substituição de um conteúdo da superstição por um conteúdo carregado de exaltação cívica. Organizar a instrução pública consistia em organizar uma nova ordem social, econômica e política, isto é, um projeto de nação. Tratava-se de uma escolarização, como instrumento de institucionalização do social, calcada em uma ideologia da unidade nacional. A ideia de uma regeneração social estava no centro desse programa de nacionalidade, nos moldes da democracia liberal francesa.

O apostolado, ao fazer a defesa da separação do Estado em relação à Igreja, exigia a supressão das academias e dos privilégios no financiamento das instituições de ensino, defendendo a família, a pátria e a humanidade como os três pilares centrais do ensinamento Rev. HISTEDBR On-line, Campinas, v.18, n.4 [78], p.963-979, out./dez. 2018 
positivista. O processo histórico em defesa do ensino público teve, no final do século XIX, na Europa, instantes de intensos debates em torno da organização de um sistema público de ensino.

Nesse sentido, o apostolado elegeu a educação como instrumento para enfrentar as forças conservadoras consideradas entraves para o encaminhamento de um projeto de modernização brasileira, fundamentada no ideário da liberdade econômica, como eixo para a ordenação de um poder nacional de exaltação dos ideais marcados pelo progresso, mas sem renunciar às liberdades.

Era preciso garantir a liberdade de testar, outro princípio importante na visão do apostolado, ao permitir que cada um cumprisse o seu dever na sociedade, na definição dos direitos e deveres. Era da constituição moral de cada indivíduo que dependeria o futuro da humanidade e a solução de seus problemas. Tais afirmações estavam fundamentadas em algumas constatações no folheto A liberdade de testar e a reorganização social (MENDES, 1907) e, segundo eles, eram constatações comprovadas cientificamente ao longo da evolução natural:

1. que tudo quanto cada um possúi pertence realmente à Humanidade, e que tudo deve ser aplicado em proveito da Humanidade; 2. que, para assegurar destino social da riqueza, torna-se indispensável a apropriaçãoi individual do capital material; resta saber como se há de garantir que o proprietário do capital humano o empregue de fato socialmente e não o esperdice em satisfações egoístas, quér pessoais, quér domésticas, quér cívicas. (MENDES, 1907, p. 03).

Os ensinos de Augusto Comte reduziam para seis horas a jornada no trabalho industrial. A introdução cada vez mais decisiva da maquinaria conduzia a esse resultado, além de conquistar, anualmente, certo número de dias de férias. Abolido o trabalho escravo, essas eram, aos olhares do apostolado, necessidades incontestáveis de todas as condições da vida realmente humana. Tais medidas eram consideradas fundamentais para da existência doméstica e para a reorganização da família proletária.

O trabalho na indústria estava condicionado, segundo os positivistas, a garantir a organização da família. Todavia, para o êxito dessas condições, o proletário deveria ter tempo para o descanso do corpo, para a cultura dos seus sentimentos e de sua inteligência no seio de uma família.

\section{CONSIDERAÇÕES FINAIS}

A questão da liberdade religiosa, aos olhares dos positivistas, consistia no maior desafio da humanidade no final do século XIX. O anticlericalismo não foi componente exclusivo ao Apostolado positivista, mas estava presente em diferentes correntes do pensamento. Os ataques à Igreja Católica eram justificados pelo fato de ela manter para si o monopólio de decisões políticas, de se associar ao Estado e insistir em certas "verdades" no 
campo educacional. As ideias do positivismo e da ideologia liberal leiga influenciaram na libertação dos escravos na Proclamação da República e intensificaram a luta em torno da questão da escola pública, leiga e gratuita e pelo ensino das ciências.

Os dirigentes do apostolado defendiam um tipo de sociedade na qual o clero fosse afastado do comando do processo educativo. Para eles, as escolas no Império estavam impregnadas pela corrupção, incompetência e, portanto, fracassavam em seus objetivos didático-pedagógicos.

A reaproximação entre Igreja-Estado, sobretudo após 1930, acabou sendo beneficiada pelo arrefecimento daquele círculo mais ortodoxo, especialmente os positivistas que eram os principais protagonistas da laicidade do Estado. A partir da Constituição de 1934, esse processo ganhou legitimidade legal ao instituir o ensino facultativo nas escolas, sendo mantido esse princípio nas constituições posteriores.

A supressão do Ensino Religioso nas escolas públicas brasileiras (com esse ou outros nomes) atendeu a um leque de interesses que uniam, nesse propósito, positivistas, maçons, protestantes e liberais de todos os matizes, o que explica o tom conciliatório de que se revestiu.

Embora a luta contra a Igreja católica tenha sido realizada por muitos, os membros do apostolado não se conformavam em ser mais um grupo no embate. Aliás, serviram-se dos resultados de todas as lutas acumuladas desde 1759, com a expulsão dos jesuítas. Seu inimigo estava muito claro e visualizado: eram os seguidores do ideário pedagógico catolicista. Os líderes do apostolado faziam uma avaliação rigorosa do sistema educacional do Império que o considerava elitista, antidemocrático e ineficiente. Eles estavam voltados ao estabelecimento das unidades nacional e mundial, ameaçadas pelas lutas de classes em marcha na Europa.

A passagem do trabalho escravo ao trabalho livre, que produziu um processo de tensão, era compreendida pelos representantes do apostolado como um estado de "anarquia" mental e espiritual. Eles se colocaram a favor da formulação de um projeto pedagógico vinculado ao processo de reconstrução nacional e, nesse contexto, a família, sobretudo, a criança, foi colocada no centro das ideias e das reformas educacionais entendidas como urgentes e necessárias.

A organização do sistema nacional de ensino na Europa se colocou como uma exigência da Revolução Industrial. No Brasil, o apostolado foi o porta-voz desse processo, considerado ideias avançadas daquele momento na Europa, fundamentado no laicismo, na medida em que defendia a ampliação do acesso à escolarização.

Os positivistas, ao adotarem essas diretrizes de pensamento, consideravam que o ensino jesuítico havia se tornado um reduto de educadores ultrapassados diante das novas exigências colocadas pela sociedade industrial. Já o discurso republicano, por sua vez, estava carregado de filosofia positivista e de apelos messiânicos, que promoveram uma importante 
valorização da educação escolar como instrumento privilegiado de disseminação do ideário republicano. Os positivistas no Brasil, muitas vezes, tomavam posições contraditórias. Eram modernizadoras ao defenderem o processo de industrialização, entretanto, diante dos desdobramentos da Revolução Industrial e dos embates entre burguesia e proletariado, assumiam uma visão política conservadora, de manutenção da ordem.

Para os representantes da Igreja Positivista, educar era essencialmente moralizar, mas também unir instrução e educação, afinal, urgia fazer o ensino moral e prático, ou seja, fazê-lo útil para a vida. A educação moral e cívica deve atravessar todas as áreas do saber, substituindo o ensino religioso. Temos aqui a perspectiva de que a ideia e o sentimento é que governam o mundo.

Ainda que tratasse os problemas nacionais como ponto de partida para suas ações, o Apostolado Positivista via como ponto de chegada o desenvolvimento alcançado na Europa, isto é, o modelo civilizatório a ser atingido naquele dado momento. As pretensões dos membros da Igreja Positivista estavam voltadas à busca de uma nova unidade social e política, que havia sido rompida com a dissolução do Império, especialmente com a abolição do trabalho escravo.

Em momentos de crise, a educação foi convocada para oferecer ensinamentos de ordem diante do "estado de anarquia" que se abatia sobre a sociedade brasileira. Nesse prisma, evidencia-se que não são os ideais que produzem a história, mas são as necessidades de um determinado momento que tecem os pilares para o contexto social e histórico. Ainda que o projeto de escolarização dos positivistas estivesse formulado, como procuramos demonstrar, as condições materiais, bem como o jogo de forças em disputa, não ofereciam todas as possibilidades para que tal proposta fosse realizada em sua plenitude. A luta pela laicidade continua sendo travada em pleno século XXI no campo da educação pública sendo identificados alguns retrocessos. As bancadas religiosas no parlamento cresceram vertiginosamente nas ultimas décadas fazendo valer suas teses acerca do ensino religioso. A questão religiosa continua ocupando parte dos debates marcada muitas vezes por negociação e conciliação. A rigor a questão da laicidade ainda não foi consolidada no Brasil.

\section{REFERÊNCIAS}

BRASIL. Constituições: Textos. Brasília: Senado Federal. Subsecretaria de Edições Técnicas, 1986. 1. v.

BRASIL. Constituição (1988): República Federativa do Brasil: 1988. Brasília: Senado Federal, 1988.

COMTE, A. Curso de filosofia positiva. São Paulo: Abril Cultural, 2000a. 
COMTE, A. Discurso preliminar sobre o conjunto do positivismo. São Paulo: Abril Cultural, 2000b.

CUNHA, L. A. A Educação brasileira na primeira onda laica: do Império à República. Rio de Janeiro: edição do autor, 2017. Disponível em: <http://www.anped.org.br/news/e-bookgratuito-educacao-brasileira-na-primeira-onda-laica-do-imperio-republica-luiz-antonio>. Acesso em: 22 set. 2017.

CUNHA, L. A. Educação e religiões: a descolonização religiosa da escola pública. Belo Horizonte: Mazza, 2013.

STF tem virada a favor de ensino religioso confessional nas escolas. [S.l.]: Em.com.br, 2017. Disponível

$<$ https://www.em.com.br/app/noticia/politica/2017/09/22/interna_politica,902589/virada-nostf-e-a-favor-de-ensino-religioso-confessional-nas-escolas.shtml>. Acesso em: 22 set. 2017.

JUNQUEIRA, S. R. A. O processo de escolarização do ensino religioso no Brasil. Petrópolis: Vozes, 2002.

MENDES, R. T. O ideal republicano de Benjamin Constant. Rio de Janeiro: Tipografia do Jornal do Commercio, 1936.

MENDES, R. T. Benjamin Constant: esboço de uma apreciação sintética da vida e da obra do fundador da república brasileira. Rio de Janeiro: Apostolado Pozitivista do Brazil, 1913.

MENDES, R. T. Ainda a atitude dos positivistas para com os católicos e demais contemporâneos. Rio de Janeiro: Igreja Apostolado Pozitivista do Brazil, 1912.

MENDES, R. T. Ainda contra o ensino obrigatório, a propózito do projeto apresentado ao conselho municipal désta cidade estabelecendo o ensino primário obrigatório. Rio de Janeiro: Igreja e Apostolado Pozitivista do Brazil, 1908.

MENDES, R. T. A atual atitude do patriciado e do proletariado perante a reorganização social: ainda a propózito das greves. Rio de Janeiro: Igreja e Apostolado Pozitivista do Brazil, 1907.

PAIM, A. (Org.). O apostolado positivista e a república. Brasília: Universidade de Brasília; Câmara dos Deputados, 1981.

SAVIANI, D. História das ideias pedagógicas no Brasil. Campinas: Autores Associados, 2007.

SILVA, J. C. "O amor por princípio, a ordem por base, o progresso por fim": as propostas do apostolado positivista para a educação brasileira (1870-1930). Cascavel: Ed. da EDUNIOESTE, 2016. 


\section{Revista HIISTTHIDBR DnHline}

\section{Artigo}

doi: 10.20396/rho.v18i4.8653196

Notas

${ }^{1}$ Doutorado em Educação pela Faculdade de educação/UNICAMP. Pós-doutorado pela Universidade Estadual do Sudoeste da Bahia/UESB. Atualmente é professor no Colégio de pedagogia e do Mestrado em Educação da Universidade Estadual do Oeste do Paraná, UNIOESTE, Campus de Cascavel. É membro do Grupo de pesquisa HISTEDOPR- História, sociedade e educação no Brasil - GT Oeste do Paraná, Cascavel. Atua na área de Educação, com ênfase em História da Educação, nos temas: questões teórico-metodológicas da história da educação, história da escola pública, instituições escolares, fontes e arquivos.

${ }^{2} \mathrm{Na}$ primeira sessão de julgamento, o advogado Fernando Neves, representante da Conferência Nacional dos Bispos do Brasil (CNBB), defendeu a obrigatoriedade do ensino religioso por estar previsto na Constituição. "O ensino religioso não é catequese, não é proselitismo. É aprofundamento daquele que já escolheu aquela fé, por si ou por sua família. Os alunos são livres para frequentar", afirmou o advogado. A ação que motivou o julgamento foi protocolada pela PGR e proposta em 2010 pela então vice-procuradora Débora Duprat. Segundo entendimento da procuradoria, o ensino religioso só pode ser oferecido se o conteúdo programático da disciplina consistir na exposição “das doutrinas, práticas, histórias e dimensão social das diferentes.

${ }^{3}$ A Constituição Federal de 1988 (BRASIL, 1988) prevê o ensino religioso nas escolas públicas brasileiras como disciplina do ensino fundamental (para alunos de 9 a 14 anos de idade), mas estabelece que a matrícula seja facultativa. Ou seja, o estudante pode recusar-se a cursar a disciplina por vontade própria ou da família.

${ }^{4}$ Livros importados da Europa traziam o registro de ideias que eram digeridas pelas elites intelectuais nas condições brasileiras, bem diversas das que propiciaram sua produção. Obras de ficção e não ficção, assim como revistas, eram disputadas nas livrarias importadoras, também editoras, como a Garnier e a Laemmert, situadas ambas na prestigiosa rua do Ouvidor.Por essa via, aqui chegaram livros como Vie de Jesus, de Renan, e Système de Politique Positive, de Comte (2000a). Renan foi mestre de pensamento de Joaquim Nabuco e de Sílvio Romero, como Comte o foi de Benjamin Constant e Sílvio Romero. Nabuco foi importante liderança política no Império, deputado e jornalista influente, enquanto Constant formou turmas de oficiais do Exército simpáticos ao Positivismo, vindo a ser protagonista da derrubada da Monarquia e da formação do primeiro governo republicano. O deputado pernambucano apenas tangenciou temas educacionais, mas o militar fluminense foi professor e dirigente de estabelecimento de ensino público. Sílvio Romero, por sua vez, exerceu a docência no ensino secundário e no superior, além de ser jornalista e escritor prolífico, mestre de pensamento até mesmo de uma presumida Escola do Recife. Cf. Cunha (2017).

${ }^{5}$ A reação da Igreja, no sentido da restauração de sua presença no Brasil, levou a um confronto inevitável com os positivistas que se colocavam como herdeiros legítimos do poder espiritual. Machado de Assis, Aluísio de Azevedo e Raul Pompéia foram os autores que deram contribuições relevantes a esse processo de laicização em defesa da liberdade religiosa. Os três escritores criticavam os privilégios detidos pela Igreja Católica e apoiavam sua separação em relação ao Estado, engrossando o movimento da imprensa, via jornais e revistas e suas charges em favor da liberdade religiosa.

${ }^{6}$ Em janeiro de 1890, o apostolado enviou ao então Governo Provisório a proposta de uma Constituição Federal com forte poder centralizador, seguindo os postulados comtianos, defendendo a liberdade como valor universal das democracias modernas. A ditadura republicana não significava uma República tirana, mas deveria estar fundada em uma ordem de liberdade, sem prevalecer os desejos e as vontades do governo sob o império da lei, que subordina a todos. A posição liberal se limitou a oferecer a igualdade jurídica, ou seja, a igualdade formal de direitos civis. Os direitos sociais, inclusive a educação e a saúde, entram na pauta dos constituintes como necessidade fundamental à vida, ante às pressões sociais e políticas, no final do século XIX, início do século XX. Diante disso, a liberdade de consciência, a liberdade econômica, a liberdade de imprensa, a liberdade de associação e de ensino e a liberdade individual não passavam, nesse contexto de privilégios, de concessões provisórias e enganadoras, retratáveis à vontade dos senhores. (FAORO, 1976, p. 450).

${ }^{7}$ A compreensão da palavra religião é buscada em seu sentido mais completo do latim religare, isto é, fazer as devidas ligações. A "religião", para o positivismo, consistia em um sentido capaz de regular a natureza individual e congregar todas as individualidades, ligando o interior pelo amor e o exterior pela fé. A convivência social exigia, acima de tudo, pôr o sentimento como preponderante ao considerar que nossas ações e pensamentos eram dirigidos por afetos. Nesse sentido, a desejada harmonia humana seria decorrente do predomínio do altruísmo, base da pedagogia positivista.

${ }^{8}$ Com a aprovação da Lei de 1905, os partidários do laicismo buscavam garantir a liberdade de consciência em conformidade com a Declaração dos Direitos do Homem e do Cidadão, relações entre o governo e a Igreja 
Católica. A nova lei proclamava a liberdade de consciência e garantia o livre exercício dos cultos, assegurando a liberdade de consciência, garantindo o livre exercício dos cultos e não subvencionando qualquer culto. Bens móveis e imóveis possuídos anteriormente pelas igrejas se tornariam propriedade do Estado que se reservava o direito de confiar gratuitamente aos representantes das igrejas e templos tendo em vista o exercício do culto. Por um lado, os ministros do culto e, em particular, os bispos, ganhariam em independência, não tendo mais de prestar contas à administração. Por outro, as igrejas e os templos não teriam mais o encargo da manutenção, bastante custosa, de seus edifícios. Teriam apenas a incumbência de assegurar a manutenção do dia a dia. Quanto aos prédios religiosos que fossem construídos a partir da lei de 1905, eles seriam de propriedade plena das respectivas entidades religiosas.

Submetido em: $17 / 08 / 2018$

Aprovado em: 11/12/2018

Publicado em: 17/12/2018 